\title{
The Effect of Problem Based Learning Model on Student Mathematics Learning Outcomes Viewed from Critical Thinking Skills
}

\author{
Heri Mulyanto ${ }^{1}$, Gunarhadi², Mintasih Indriayu ${ }^{3}$
}

\section{ARTICLE INFO}

Article History:

Received 21.01.2018

Received in revised form

21.03.2018

Accepted

Available online 01.04.2018

\begin{abstract}
This study aims to determine the effect of applying problem based learning model on students' mathematics learning outcomes viewed from critical thinking skills of fifth grade students of the private primary school in the Surakarta region. This research is an experimental research using sample of 309 students consisting of experimental class of 153 students and control class of 156 students. Method of data analysis using Two-Way Anova. Results of this study indicate (1) There are significant differences in mathematics learning outcomes between students who following Problem Based Learning model with conventional model (2) There is a significant difference in mathematics learning outcomes between students who have high and low critical thinking skills. (3) There is no interaction effect between learning model and critical thinking skills on mathematics learning outcomes.
\end{abstract}

C 2018IJERE. All rights reserved

Keywords: Learning outcome, mathematics, learning, problem based learning, conventional, critical thinking skills

\section{INTRODUCTION}

Experimental research about effect interaction of learning model with critical thinking skill on learning achievement of mathematics of private primary school students in Surakarta is important. This research motivated by survey results of researcher, that results of science and mathematics learning achieved of fifth grade of the private primary school in Surakarta has not been maximized. Causes factor can be derived from the teacher factor that is learning model has not aroused the creativity of student thinking. Mathematics learning is still teacher-oriented so that students are less actively involved in learning, problem-solving and less critical thinking skills. Related with the problem, teachers need to develop innovative learning models such as Problem Based Learning (PBL).

Problem-solving is important for students to become effective problem solvers in their profession, and for later career success (Mazumder, 2014). The problem-based learning is focused on problems in which students can construct their own knowledge, develop inquiry and thinking skills to a higher level. Students should be able to formulate a temporary answer to a problem requiring logical intelligence, courage and active solution with in real situation. Students also need to improve their independence, self-confidence and endurance to solve the problem (Talib and Kailani, 2014). According to Sanjaya (2007) Problem Based Learning (PBL) is a series of learning activities that emphasize the process of solving problems faced scientifically. According to Glatthorn and Craft-Tripp (in Pecore, 2012) Problem Based Learning is a learning model based on constructivism theory that will make the students interest in learning and actively participate in the learning process. According to Muraray-Harvey, Pourshafie, and Reyes (2013) one way to create active learning is to apply problem-based learning models. Problem-based learning models emphasize broader teaching and learning activities processes, creating opportunities to develop meaningful knowledge, skills and attitudes related to collaborative learning, so as to build cooperative knowledge, help students to establish explicit relationships between attitudes toward cooperation and achieve learning outcomes, and identify specific collaborative skills required by students, and obtained through group collaboration. The theory developed by Glatthorn and Craft-Tripp (in Pecore, 2012), states Problem Based Learning is a model of learning based on constructivism theory that will make students interested in learning and active participation in the learning process. According to Muraray-Harvey, Pourshafie, and Reyes (2013) one way to create active learning is to apply problem-based learning models. The problembased learning model emphasizes the broader process of teaching and learning, creating opportunities to 
Mulyanto,H., Gunarhadi, Indriayu,M. (2018). The effect of problem based learning model on student mathematics learning outcomes viewed from critical thinking skills. International Journal of Educational Research Review,3(2),37-45.

develop meaningful knowledge, skills and attitudes related to collaborative learning, so as to build cooperative knowledge, help students to establish explicit relationships between attitudes toward cooperation and achieve learning outcomes; identify specific collaborative skills required by students, and obtained through group collaboration. The results of Frank (2011) suggest that a scientific approach in mathematics learning to improve skills and skills is therefore a strong constraint on basic education. In addition, the scientific approach can also improve competence in modern mathematics learning. Several strikes of problem based learning model such as a) problem solving is a good technique to better understand the content of the lesson; b) problem solving can improve students' ability and provide satisfaction to discover new knowledge by students; c) problem solving can increase student activity during the learning process (Lian, 2010).

Mathematics learning outcome can also be influenced from student factors that is critical thinking skill. The theory proposed by Chaffe (2012: 4) states that critical thinking is the process of thinking to clarify one's understanding of something resulting in an intelligent decision. According to Moon (2008) critical thinking is the ability to consider various information obtained from various different sources, then process them creatively and logically and analyze them to get the right conclusions. Previous research results of Karim and Normaya (2015) states that one of the primary goals of schooling is to form students' critical thinking skills and one of the subjects considered to teach critical thinking skills is mathematics. A child's skill to think critically well can shape behavior when dealing with problems with rational thought. Previous survey results in one of the private primary schools in Surakarta show that students only study mathematics drill, memorize concepts, theories, and test or test-oriented. Students are accustomed to receiving lessons from teacher and not trying to find or shape their own knowledge. Facione (2015) states, students critical thinking skills can be measured with six dimensions of Interpretation, Analysis, Inference, Evaluation, Explanation, and Self-Regulation.

Previous research findings conducted by Ajai et al. (2013) states that there is a significant difference in post-test results of mathematics students based on learning models, post-test results of mathematics students who follow the PBL model learning is higher than conventional model. Previous research findings conducted by Fatade et al. (2013) states that there is a significant difference in post-mathematics test result of junior high school students in Nigeria based on learning model, post-test result of mathematics of students who follow PBL model learning is higher than control class students. The findings of previous research conducted by Fazriyah et al. (2017) stated that there is a significant difference of science learning outcomes of fifth grade students of Primary School Depok based on critical thinking skills. Students who have high critical thinking skills, students' science learning outcomes given an integrative thematic learning model is higher than in the fragmented learning model. Students who have low critical thinking skills, higher learning outcomes of Natural Science use a fragmented model. Previous research findings conducted by Erwin, Tellu and Kundera (2015) states there are significant differences in student learning outcomes in Biology lesson in 4 Senior High School of Palu City in terms of students' critical thinking skills. Student learning outcomes that have high critical thinking skills is higher than students who have low critical thinking skills. The findings of this study support the results of previous research conducted by Nurwulandari, Muhardjito, and Mufti (2015) that there are significant differences in problem-solving abilities in terms of critical thinking skills in class X students in 1 Senior High School of Malang city Year 2014/2015. Students with high critical thinking skills have higher problem-solving abilities than students with low critical thinking skills.

The results of a previous survey on one of the private primary schools in Surakarta showed that students only learn mathematics drill, memorize concepts, theories, and test or test-oriented. Students are accustomed to receiving lessons from what the teacher just says and not trying to find or shape their own knowledge. The problem motivates the researcher to analyze the influence of learning problem based learning model and critical thinking skills toward mathematics learning result and to analyze the influence of interaction between problem based learning model with critical thinking skills toward mathematics learning outcomes in V students of private primary school in Surakarta region.

Based on the problems and findings of previous research the researcher took the initiative to conduct research on the effect of Learning Problem Based Learning Model on Srudent Mathematics Learning Outcomes Viewed from the Critical Thinking Skills 
Mulyanto,H., Gunarhadi, Indriayu,M. (2018). The effect of problem based learning model on student mathematics learning outcomes viewed from critical thinking skills. International Journal of Educational Research Review,3(2),37-45.

\section{METHOD}

This research is an experimental research using sample of 309 private primary school students in five sub-districts of Surakarta city in Year 2016/2017. Sample consists of experiment class are 153 students and control class are 156 students. The experimental class is a group of students who are subject to learning with a Problem Based Learning model (PBL) while the control class is a group of students who are subjected to conventional learning. Dependent variable in this research is mathematics learning outcomes. Dependent variables in this research are (1) learning PBL model and (2) critical thinking skills. Instrument of critical thinking skills in the form of questionnaires consists of 20 items of statements measured by six dimensions developed by Facione (2015) namely Interpretation, Analysis, Inference, Evaluation, Explanation, and SelfRegulation. This instrument presents two alternative answers Yes and No. The measurement scale for each odd numbered question gets a value of 5 for each item if it answers "Yes" ("No" $=0$ ). For each even numbered question get a value of 5 for each item if it answers "No" ("Yes" = 0 ). The Cut of Point> 70 indicator is said to be critical. Measurement instrument of mathematics learning outcomes test aims to measure the understanding of fifth grade students of the primary school on the characteristics of wake and inter-wake relationship with basic competence to identify the properties of wake-up and investigate the nature of congruence and symmetry. Instrument of mathematics learning outcomes test consists of 30 question items by presenting 4 alternative answers. Measurement scale of the mathematics learning outcomes test is the score of 1 for the right answer and the score 0 for the wrong answer. Prior to the study all of these instruments have fulfilled the instrument feasibility test both the level of validity and reliability. Method of data analysis using two path or factorial $2 \times 2$ Anava. Before done data analysis, first do test requirement analysis that is test of normality and homogeneity.

Table 1: Two-way Anova Design

\begin{tabular}{cccc}
\hline & Variable $\mathrm{X}_{1}$ & \multicolumn{2}{c}{ Learning Model } \\
\cline { 3 - 4 } Variable $\mathrm{X}_{2}$ & & PBL $\left(\mathrm{A}_{1}\right)$ & Konventional $\left(\mathrm{A}_{2}\right)$ \\
\hline \multirow{2}{*}{ Critical Thinking Skills } & High $\left(\mathrm{B}_{1}\right)$ & $\mathrm{A}_{1} \mathrm{~B}_{1}$ & $\mathrm{~A}_{2} \mathrm{~B}_{1}$ \\
& Low $\left(\mathrm{B}_{2}\right)$ & $\mathrm{A}_{1} \mathrm{~B}_{2}$ & $\mathrm{~A}_{2} \mathrm{~B}_{2}$ \\
\hline
\end{tabular}

\section{RESULT, DISCUSSION, AND SUGGESTIONS}

a. Test of Assumptions for ANOVA

The requirements of data analysis using parametric statistics are data obtained normal and homogeneous distributions. Normality test using kolmogorov-smirnov analysis and homogeneity test using Levene's test.

1) Normality test

Table 1 below presents result of normality test of data mathematics learning outcome through Problem Based Learning model and conventional model.

Table 2: Result of Normality Test of Mathematics Learning Outcome Viewed from Learning Model

\begin{tabular}{|c|c|c|c|c|c|c|}
\hline & \multirow{2}{*}{$\begin{array}{c}\text { Learning } \\
\text { Model }\end{array}$} & \multicolumn{3}{|c|}{ Kolmogorov-Smirnov } & \multirow{2}{*}{ Decision } & \multirow{2}{*}{ Conclusion } \\
\hline & & Stat. & Df & Sig. & & \\
\hline Mathematics & PBL & 0,068 & 153 & 0,082 & $\begin{array}{c}\text { Ho } \\
\text { supported }\end{array}$ & $\begin{array}{c}\text { Distributed } \\
\text { normally }\end{array}$ \\
\hline $\begin{array}{l}\text { learning } \\
\text { outcomes }\end{array}$ & Konventional & 0,065 & 156 & 0,200 & $\begin{array}{c}\text { Ho } \\
\text { supported }\end{array}$ & $\begin{array}{c}\text { Distributed } \\
\text { normally }\end{array}$ \\
\hline
\end{tabular}

Normality test with Kolmogorov-Smirnov analysis showed that the data of mathematics learning outcome through Problem Based Learning model and conventional model came from normal distributed population indicated by Sig. $>0.05$.

The following table 2 shows the result of normality test of data mathematics learning outcome viewed High and Low Critical Thinking Skills 
Mulyanto,H., Gunarhadi, Indriayu,M. (2018). The effect of problem based learning model on student mathematics learning outcomes viewed from critical thinking skills. International Journal of Educational Research Review,3(2),37-45.

Table 3: Result of Normality Test of Mathematics Learning Outcome Viewed from Critical Thinking Skills

\begin{tabular}{ccccccc}
\hline & Critical & \multicolumn{2}{c}{ Kolmogorov-Smirnov } & Decision & Conclusion \\
& $\begin{array}{c}\text { Thinking } \\
\text { Skills }\end{array}$ & Stat. & Df & Sig. & & \\
\hline $\begin{array}{c}\text { Mathematics } \\
\text { learning } \\
\text { outcomes }\end{array}$ & Low & 0,064 & 174 & 0,076 & Ho supported & Distributed normally \\
& High & 0,075 & 135 & 0,061 & Ho supported & Distributed normally \\
\hline
\end{tabular}

Normality test by Kolmogorov-Smirnov analysis showed that the data of mathematics learning outcome viewed on high and low level of critical thinking skills came from normally distributed population, this is indicated by Sig. $>0.05$.

2) Homogeneity Test

Table 3 below presents the homogeneity test of mathematics learning outcomes viewed from learning model and critical thinking skills.

Table 4: Results of Homogeneity Test of Mathematics Learning Outcomes Viewed from Learning Model and Critical Thinking Skills

\begin{tabular}{cccccc}
\hline F & df1 & df2 & Sig. & Decision & Conclusion \\
\hline 1,662 & 3 & 305 & 0,175 & Ho supported & Homogen \\
\hline
\end{tabular}

Results of homogeneity test show that the data of mathematics learning outcome viewed from learning model and critical thinking skills come from population having equal/homogeneous variance, this is indicated by Sig. $>0.05$.

b. Two-Way Anova

Two-Way Anova Test aims to examine the effect of learning models and critical thinking skills and interaction effect of learning models and critical thinking skills on mathematics learning outcomes. Testing of Two-Way Anova using SPSS program summarized as the following table.

Table 5: Result of Two-Way Anova

\begin{tabular}{ccccccc}
\hline Source & Sum of Squared & Df & Mean Squared & F & Sig. & Ho \\
\hline Model & 1454,743 & 1 & 1454,743 & 7,013 & 0,009 & Supported \\
CTS & 2270,971 & 1 & 2270,971 & 10,948 & 0,001 & Supported \\
Model $^{*}$ CTS & 22,940 & 1 & 22,940 & 0,111 & 0,740 & Rejected \\
\hline
\end{tabular}

1) Differences in mathematics learning outcomes between students who following the learning of Problem Based Learning model with conventional model

Hypothesis 1 tested:

Ho: there is no difference in mathematics learning outcomes between students who following the learning of Problem Based Learning model with conventional model

H1: there are differences in mathematics learning outcomes between students who following the learning of Problem Based Learning model with conventional model

From the calculation of Anova (Table 4) obtained F-statistics 7.013 with Sig $0.009<0.05$ means Ho is rejected and $\mathrm{H} 1$ accepted. Means there is a significant difference in mathematics learning outcomes between students who following the learning of Problem Based Learning model with conventional model. Students who following the PBL model achieve higher learning outcomes than students who following conventional model. 
Mulyanto,H., Gunarhadi, Indriayu,M. (2018). The effect of problem based learning model on student mathematics learning outcomes viewed from critical thinking skills. International Journal of Educational Research Review,3(2),37-45.

2) Differences in mathematics learning outcomes between students who have high Critical Thinking Skills with Low Critical Thinking Skills

Hypothesis 2 tested:

Ho : there is no difference in mathematics learning outcomes between students who have high Critical Thinking Skills with Low Critical Thinking Skills.

$\mathrm{H} 2$ : there is a difference in mathematics learning outcomes between students who have high Critical Thinking Skills with Low Critical Thinking Skills.

From the calculation of Anova (Table 4) obtained F-statistics 10,948 with Sig $0.001<0.05$ means Ho is rejected and $\mathrm{H} 2$ is accepted. This means that there are significant differences in mathematics learning outcomes between students who have high and low critical thinking skills. Students who have high critical thinking skills achieve higher learning outcomes than students with low critical thinking skills.

3) Interaction effect between learning model with critical thinking skills on mathematics Hypothesis 3 tested:

Ho : there is no interaction effect between learning model with critical thinking skills on mathematics learning outcomes.

H3: there is interaction effect between learning model with critical thinking skills on mathematics learning outcomes

From the calculation of Anova (Table 4) obtained F-statistics 0,111 with Sig $0.740>0.05$ means Ho accepted and $\mathrm{H} 3$ rejected. Means there is no interaction effect between learning model with critical thinking skills on mathematics learning outcomes. Thus, there is no difference in mathematics learning outcomes in both learning models in students with high or low critical thinking skills.

Based on the results of this study obtained the findings, that there are significant differences in mathematics learning outcomes between students who following learning of Problem Based Learning model with students who following conventional model. This is showed from Anova results with Sig. $(0.009)<0.05$. Based on the mean value of the mathematics learning outcomes of the two sample groups showed a significant difference that the mean value of the students following the Problem Based Learning model $(73,68)$ was higher than the mean value of the students who following conventional model $(67,92)$. Result of the observation showed the difference of students behavior, students activity in discussion, ability to analyze and solve the problem, liveliness to ask questions, activeness of doing the exercise questions for the experimental group students is higher than the control group students. Based on the findings of this study, PBL model emphasizes on learning by doing means students are invited to play an active role in learning activities because teachers give students the freedom to solve and learn ways or alternatives solving mathematical problems posed, so that students will be accustomed to solve critical problems critically and independent. The findings of this study support the results of previous studies conducted by Ajai et al. (2013) that there is a significant difference of post-test result of mathematics of students based on learning model, post test result of mathematics of students who follow PBL model learning is higher than conventional model. The findings of this study support the results of previous studies conducted by Fatade et al. (2013) that there is a significant difference of post test result of mathematics of junior high school students in Nigeria based on learning model, post test result of mathematics of students who follow PBL model learning is higher than control class students.

Based on the results of this study obtained the findings, that there are significant differences in the mathematics learning outcomes between students who have high critical thinking skills with students who have low critical thinking skills. This is evidenced from Anova results with Sig. $(0.001)<0.05$. Differences in mathematics learning outcomes of students in terms of the high critical thinking skills and low critical thinking skills indicate different results on the tendency of students to perform cognitive processes that lead students to interpret, analyze, evaluate, inference, eksplanation, and self-regulation of a problem and mathematical problem solving. Thus, students cognitive ability to interpret, analyze, evaluate, conduct inference, explanation, and self-regulation is higher in students who have high critical thinking skills compared with students who have low critical thinking skills. The findings of this study support the results 
of previous research conducted by Fazriyah (2015) that there is a significant difference of science learning outcomes of fifth grade students in Primary School Depok viewed on critical thinking skills. Students who have high critical thinking skills, science learning outcomes of students given an integrative thematic learning model is higher than in the fragmented learning model. Students who have low critical thinking skills, higher learning outcomes of sciene use a fragmented model. The findings of this study support the results of previous research conducted by Erwin, Tellu and Kundera (2015) that there are significant differences in student learning outcomes in Biology lesson in 4 Senior High School of Palu city in terms of students critical thinking skills. Student learning outcomes that have high critical thinking skills is higher than students who have low critical thinking skills. The findings of this study support the results of previous research conducted by Nurwulandari, Muhardjito, and Mufti (2015) that there are significant differences in problem-solving abilities in terms of critical thinking skills in class X students in 1 Senior High School of Malang city Year 2014/2015. Students with high critical thinking skills have higher problem-solving abilities than students with low critical thinking skills.

Based on the results of this study obtained the findings, that there is no interaction effect between learning models with critical thinking skills on mathematics learning outcomes. This is evidenced from Anova results with Sig. (0.740) $>0.05$. Thus, simultaneously the factor of learning model and critical thinking skills do not give significant effect on students mathematics learning outcomes. In other words, learning model and critical thinking skills have influence partial on learning outcomes. To see and ascertain whether there is an interaction effect or not between learning models with critical thinking skills on mathematics learning outcome can be seen in the following graph:

\section{Estimated Marginal Means of Mathematics Learning Outcome}

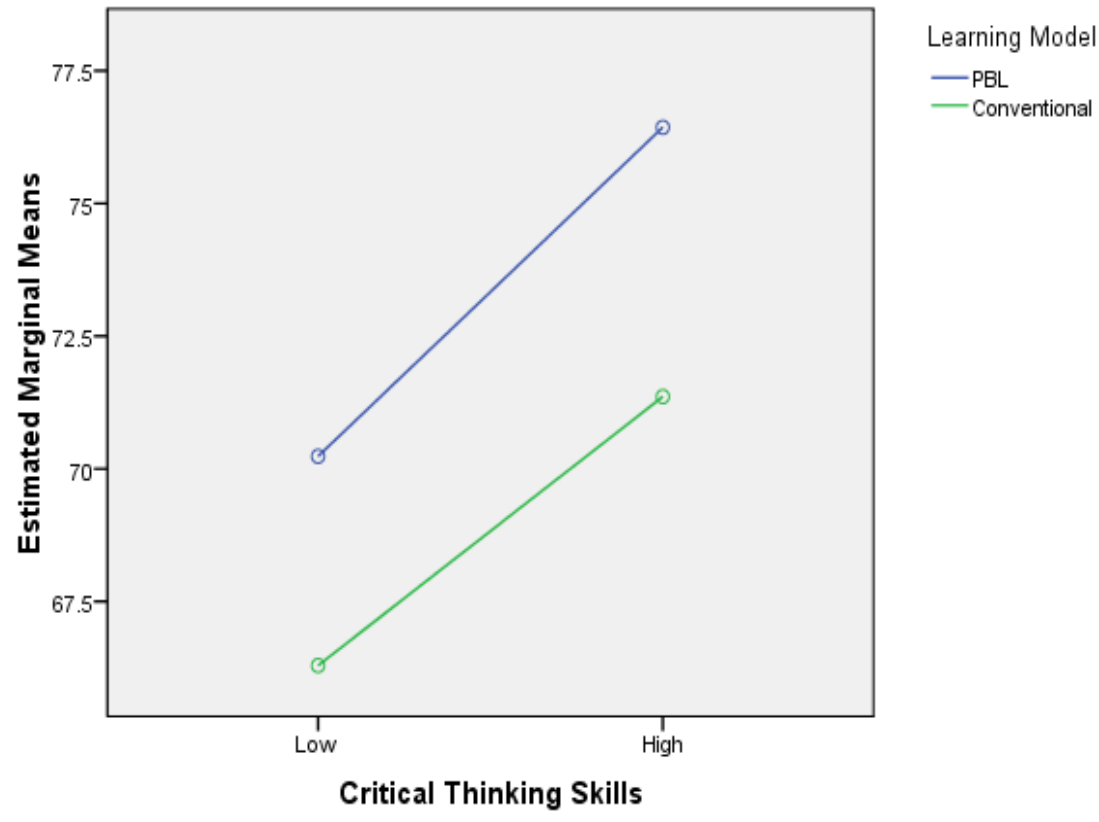

Figure 1: Graph of Interaction Effect Between Learning Models with Critical Thinking Skills on Mathematics Learning Outcomes

According to Ghozali (2005: 59) Anova used to determine the main effect and interaction effects of independent variables (factors) on dependent variable. The main effect is the direct effect of independent variable on dependent variable, while the interaction effect is the effect of the two or more independent variables on dependent variable. To know the interaction effect other than can be seen from $F$ statistic value and significance value, also can be seen from graph explaining the existence or absence of interaction between two factors. If two lines of the two factors intercept each other there is an interaction between the two factors. Conversely, if two lines of the two factors are not mutually intercepted there is no interaction between the two factors. From the results of data analysis with two-way anova generated graphs that describe applied of learning model to the two classes of Problem Based Learning model and conventional 
Mulyanto,H., Gunarhadi, Indriayu,M. (2018). The effect of problem based learning model on student mathematics learning outcomes viewed from critical thinking skills. International Journal of Educational Research Review,3(2),37-45.

model with critical thinking skills that exist in students both high and low critical thinking skills. Based on the statement presented by Ghozali (2005: 59) can be obtained understanding, if there is an interaction between these two variables on mathematics learning outcomes, it will occur intersection between the graph of learning models with critical thinking skills. From the graph above, it can be seen that the two lines of both factors (learning model with critical thinking skills) do not cut each other, thus there can be no interaction effect between learning model and critical thinking skills on students matematics learning outcomes. In addition, each factor of learning model and critical thinking skills are not interdependent and influential but only have their own position on the learning outcomes. With no proven hypothesis three in this study can interpret that, this research model only use learning model and critical thinking skills as factor influencing mathematics learning outcomes. While outside the model of this study, there are still control variables that also influence the mathematics learning outcomes. Control variables that influence student learning outcomes can be sourced from internal factors such as students interest in learning, intelligence and external factors such as the use of learning media, learning conditions, and so forth. According to Gagne and Brings in Jamil (2012: 37) understanding of learning outcomes is the abilities that students have as a result of learning and can be observed through the performance of students. According to Anitah (2007: 27) the realization of behavioral changes of learning outcomes is an increase in the ability of students in accordance with the goals set. The success of achieving good learning outcomes in teaching and learning activities is influenced by two factors: the factors of within the students (intern) and factors from outside the student self (extern). The inner factors of the students that influence the learning outcomes include interest, talent, skill, effort, motivation, attention and health. Factors from outside students that influence the learning outcomes include physical and non physical environment. The physical environment in this case is learning tools, media, teachers and friends learn. The theory of learning methods proposed by Smith (in Jamil, 2012: 154) is an external factor that can affect student learning outcomes, the method of learning is the technical means taken by teachers to create teaching situations and can be developed for the implementation of learning with the aim to improve learning outcomes students. The theory proposed by Facione (2010: 5) explains that the aspect of critical thinking skills related to one's cognitive abilities is also an internal factor of students that can influence learning outcomes. The theory proposed by Chaffe (2012: 4) explains that critical thinking is the process of thinking to clarify one's understanding of something resulting in an intelligent decision. Based on these theories can be obtained understanding that the high low student learning outcomes can be influenced by many factors both internal factors and external factors. Based on the findings of this study, the absence of interaction influence between the two factors (learning model and critical thinking skills) on the result of learning mathematics can be caused because there are still many situational factors that can give effect (influence) on the improvement of learning outcomes both factors from within students as well as factors from outside the students. So based on these findings, the increase in mathematical learning outcomes can be explained from the effects alone from both factors. The findings of this study support the results of previous research conducted by Erwin, Tellu and Kundera (2015) that there is no interaction between learning models and critical thinking skills of students on learning outcomes in Biology lessons in SMA Negeri 4 Palu. The findings of this study support the results of previous studies conducted by Widyatiningtyas et al. (2015) that there is no significant interaction between the learning models and the early ability of mathematics to the critical thinking skills of mathematics in high school students in Bandung. The findings of this study support the results of previous research conducted by Tijayanti and Marzuki (2014) that there is no significant interaction between the learning method and the type of intelligence on the development of students critical thinking skills in SMA Negeri 1 Suela Lombok Timur. The findings of this study support the results of previous research conducted by Ali (2012) that there is no interaction between learning approaches and the level of early knowledge of mathematics students to improve the critical thinking skills of mathematic of the junior high school students. The findings of this study support the results of previous research conducted by Risqi (2013) that there is no interaction between CTL and PBL methods with students creativity in learning mathematics on the achievement of seven grade students in SMP Muhammadiyah 5 Ngawi year 2013/2014.

Based on the results of research and discussion, can be concluded as follows (1) There are significant differences in mathematics learning outcomes between students who following Problem Based Learning model with conventional model of fifth grade students of the private primary school in Surakarta Region Year 2016/2017. Students who following Problem Based Learning model get higher learning 
Mulyanto,H., Gunarhadi, Indriayu,M. (2018). The effect of problem based learning model on student mathematics learning outcomes viewed from critical thinking skills. International Journal of Educational Research Review,3(2),37-45.

outcomes than students who following conventional model (2) There is a significant difference in mathematics learning outcomes between students who have high and low critical thinking skills of fifth grade students of the private primary school in Surakarta Region Year 2016/2017. Students who have high critical thinking skills achieve higher learning outcomes than students with low critical thinking skills. (3) There is no interaction effect between learning model and critical thinking skills on mathematics learning outcomes of fifth grade students of the private primary school in Surakarta Region Year 2016/2017. There is no difference in mathematics learning outcomes in both learning models in students with high or low critical thinking skills.

Based on the conclusions from this study, teacher is suggested to improve regular meetings in the Teachers Working Group to discuss on the use of PBL model learning. Principal suggested supporting teachers in implementing learning innovation through workshop or in house training.

Further research is suggested to expand the research sample at public and private elementary school in Central Java area, so that research results can more be generalized. Furthermore, there is still a need for research to analyze the difference of mathematics learning outcomes by comparing between problem based learning with other model, so that the result will be more developed.

\section{REFERENCES}

Ali, S. (2012). Peningkatan kemampuan berpikir kritis matematis siswa SMP melalui pendekatan contextual teaching and learning. Jurnal Edumatica, 2(1), 45-57.

Anitah, S. W. (2007). Strategi pembelajaran di SD. Jakarta: Universitas Terbuka.

Chaffe, J. (2012). Thinking critically. USA: Wadsworth Cengage Learning.

Erwin, M., Tellu, H. A. T., \& Kundera, I. N. (2015). Perbandingan hasil belajar biologi yang diajar menggunakan model cooperative integrated reading and composition (CIRC) dengan menggunakan model pembelajaran langsung berdasarkan keterampilan berpikir kritis siswa SMA Negeri 4 Palu. eJurnal Mitra Sains, 3 (1), 20-27.

Facione, P. A. (2015). Critical thinking: what it is and why it counts. 1-30. Retrieved from: http://www.insightassessment.com

Fatade, A. O., Mogari, D., \& Arigbabu, A. A. (2013). Effect of problem based learning on senior secondary school students' achievements in further mathematics. Internasional Journal Acta Didactica Napocensia, 6(3), 27-49.

Fazriyah, N., Supriyati, Y., \& Rahayu, W., (2017). The effect of integrated learning model and critical thinking skill of science learning outcomes. Journal of Physics, 8(2), 1-5.

Frank, Quinn. (2011). A science of learning approach to mathematics education. Journal Notices of The American Mathematical Society, 58(9), 1264-1275.

Johnson, Elaine B. (2009). Contextual teaching and learning, menjadikan kegiatan belajar-mengajar mengasyikkan dan bermakna. Bandung : Mizan Media Utama.

Ghozali, I. (2005). Aplikasi analisis multivariate dengan program SPSS. Semarang: Badan Penerbit Universitas Diponegoro.

Jamil, S. (2012). Strategi pembelajaran, teori dan aplikasi. Yogyakarta: AR-Ruzz Media. 
Mulyanto,H., Gunarhadi, Indriayu,M. (2018). The effect of problem based learning model on student mathematics learning outcomes viewed from critical thinking skills. International Journal of Educational Research Review,3(2),37-45.

John T.A., Benjamin I.I., \& Emmanuel, I.O. (2013). Comparison of the learning effectiveness of problem based learning (PBL) and conventional method of teaching algebra. Journal of Education and Practice, 4(1), 131136.

Karim \& Normaya. (2015). Kemampuan berpikir kritis siswa dalam pembelajaran matematika dengan menggunakan model jucama di sekolah menengah pertama. Jurnal Pendidikan Matemática, 3(1), 92-104.

Mazumder, Q., (2014). Student motivation and learning strategies of students from usa, china and bangladesh, International Journal of Evaluation and Research in Education (IJERE), 3(4), 205-210.

Lian, I. T. A. (2010). Determining the readiness of staff for PBL training and development, PBL ReflectionInternational PBL Symposium, 9, 4-10.

Moon, J. (2008). Critical thinking an exploration of theory and practice. USA: Routledge.

Murray-Harvey, R., Pourshafie. T., \& Rayes, S. W. (2013). What teacher education students learn about collaboration from problem-based learning. Journal of Problem Based Learning in Higher Education, 1(1), 114-134.

Nurwulandari, N., Muhardjito, \& Mufti, N. (2015). Pengaruh real-world applications inquiry terhadap kemampuan pemecahan masalah fisika ditinjau dari kemampuan berpikir kritis siswa pada siswa kelas X SMA. Prosiding Pertemuan Ilmiah XXIX HFI Jateng and DIY, Yogyakarta 25 April, 297-300.

Pecore, J. L. (2012). Beyond beliefs: teachers adapting problem-based learning to preexisting systems of practice. Interdisciplinary Journal of Problem-Based Learning, 7(2), 8-30.

Risqi, Y. (2013). Pembelajaran matematika menggunakan metode contextual teaching and learning (CTL) dan problem based learning (PBL) pada pokok bahasan kubus dan balok ditinjau dari kreativitas siswa kelas VIII SMP Muhammadiyah 5 Ngawi semester genap tahun pelajaran 2013/2014. Jurnal Akademis dan Gagasan Matematika, 1(3), 18-24.

Sanjaya, W. (2007). Strategi pembelajaran (3rd ed.). Jakarta: Kencana Prenada Media Group.

Talib, A. \& Kailani, I. B., (2014). Problem based learning in cooperative situation (PBLCS) and its impact on development of personal intelligence. International Journal of Evaluation and Research in Education (IJERE), 3(4), 236-244.

Tijayanti, I., \& Marzuki. (2014). Keefektifan metode problem solving dalam pembelajaran PKN untuk pengembangan kemampuan berpikir kritis dan sikap nasionalisme di SMA Negeri 1 Suela Lombok Timur. SOCIA-Jurnal Ilmu-ilmu Sosial, 2, 173-182.

Widyatiningtyas, R., Kusumah, Y. S., Sumarmo, U., \& Sabandar, J. (2015). The impact of problem-based learning approach to senior high school students' mathematics critical thinking ability. IndoMS-JME, 2, 30-38. 